\title{
CAROTENOIDS PROFILE AND TOTAL POLYPHENOLS IN FRUITS OF Pereskia aculeata MILLER ${ }^{1}$
}

\author{
TÂNIA DA SILVEIRA AGOSTINI-COSTA², DANIELLE CRISTINA WONDRACECK ${ }^{3}$, \\ WESLEY DA SILVEIRA ROCHA ${ }^{3}$, DIJALMA BARBOSA DA SILVA ${ }^{2}$
}

ABSTRACT - Pereskia aculeata Mill. (Ora-pro-nóbis) is a native cactaceae from tropical America, whose leaves have high protein content. In Brazil it is found in all territorial extension between the states of Bahia and Rio Grande do Sul. Most studies have focused on chemical characterization of the leaves of this specie. The objective was to assess the carotenoids profile and the total polyphenols present in the fruits of P. aculeate. Carotenoids were determined by HPLC-PAD (high performance liquid chromatography - photodiode array detector), total polyphenols were determined by Folin-Ciocalteu and vanillin methods. Trans- $\beta$-carotene was the main carotenoid, followed by $\alpha$-carotene, lutein and other minor carotenoids. It was found $64.9 \pm 1.1$ mg. $100 \mathrm{~g}^{-1}$ of gallic acid equivalent, $14.8 \pm 0.2 \mathrm{mg} .100 \mathrm{~g}^{-1}$ of catechin equivalent. Carotenoid identification of $P$. aculeate fruits are presented here by the first time and indicate that these fruits can be researched as source of bioactive substances, especially antioxidant and provitamin A carotenoids.

Index terms: ora-pro-nóbis, $\beta$-carotene, lutein, vitamin A.

\section{PERFIL DE CAROTENOIDES E FENÓLICOS TOTAIS EM FRUTOS DE Pereskia Aculeata MILLER}

RESUMO - A espécie Pereskia aculeata Mill. (ora-pro-nóbis) é uma cactácea nativa da América Tropical, cujas folhas apresentam elevado teor protEico. No Brasil, é encontrada desde o Estado da Bahia até o Rio Grande do Sul. A maioria dos estudos sobre ora-pro-nóbis concentra-se na caracterização química das folhas desta espécie. O objetivo foi identificar o perfil de carotenoides e avaliar o teor de polifenóis totais em frutos de P. aculeata. Os carotenoides foram determinados por CLAE-DAD (cromatografia líquida de alta eficiência - detector de arranjo de diodos), os fenólicos totais pelos métodos de Fólin-Ciocalteou e da vanilina. O trans- $\beta$-caroteno foi o principal carotenoide, seguido pelo $\alpha$-caroteno, luteína, além de outros carotenoides minoritários. Foram encontrados $64,9 \pm 1,1 \mathrm{mg} .100 \mathrm{~g}^{-1}$ de ácido gálico equivalente; 14,8 $\pm 0,2$ mg. $100 \mathrm{~g}^{-1}$ de catequina equivalente. A identidade dos carotenóides presentes em frutos de P. aculeata está sendo apresentada pela primeira vez e indica que estes frutos devem ser pesquisados como fontes de substâncias bioativas, especialmente de carotenóides com atividades antioxidante e pró-vitamina A.

Termos para indexação: ora-pro-nóbis, $\beta$-caroteno, vitamina $\mathrm{A}$, luteína.

\section{INTRODUCTION}

Pereskia aculeata Miller. (Cactaceae), also know as ora-pro-nobis or American gooseberry, is a native plant of the American Tropics. In Brazil, this cactacea can be found throughout the territorial extension between the states of Bahia and Rio Grande do Sul, mainly along the restinga and areas along the coast stony sea (SILVA JUNIOR, 2008). This specie is a declared environmental weed in some countries, as South Africa (PATERSON et al., 2009). Paradoxically, the aqueous extract and mucilage of leaves shows promising pharmacological results (VALENTE et al, 2007; SILVA-JUNIOR,
2007). The lack of toxicity of this plant and its higher content of fiber and arabinogalactans make P. aculeata agriculturally and economically important as a food source (MERCÊ et al., 2001; SILVA-JUNIOR, 2008). Seventy seven percent of the population of the Diamantina $(\mathrm{MG})$ eats this rich unconventional vegetable (DIAS et al., 2005).

Pereskia aculeata produces fruits between June and July. The fruit is pomaceous, type cactidio, with succulent hypanthium, pericarp and seeds immersed in a gelatinous mass (ROSA; SOUZA, 2003); its color varies between yellow and red. The small fruits ( 1.8 to $2.0 \mathrm{~g})$ may be consumed fresh or as jam, syrup or juices. The edible fruits have 1

\footnotetext{
'( Trabalho 130-11). Recebido em: 20-04-2011. Aceito para publicação em: 11-10-2011. Financial support: Embrapa.

${ }^{2}$ Researchers/ Embrapa Genetic Resources and Biotechnology, Parque Estação Biológica, PqEB, W5 Norte, final, CEP: 70770-900, Brasília-DF. E-mails: tania@cenargen.embrapa.br; dijalma@cenargen.embrapa.br.

${ }^{3}$ Biologists,scholarships from Embrapa Genetic Resources and Biotechnology, Brasília-DF. E-mails: daniele.wondraceck@gmail.com; biosrocha@yahoo.com.br
} 
$\%$ of protein, $0.7 \%$ of lipid, $6.3 \%$ of carbohydrate, $0.7-9.4 \%$ of fiber; $2-125 \mathrm{mg} .100 \mathrm{~g}^{-1}$ of vitamin C; $0.9 \mathrm{mg} .100 \mathrm{~g}^{-1}$ of niacin, $174-206 \mathrm{mg} .100 \mathrm{~g}^{-1}$ of calcium and $26 \mathrm{mg} \cdot 100 \mathrm{~g}^{-1}$ of phosphorus. According to SILVA-JUNIOR (2008) the antioxidant activity of the fruits $(1 \mathrm{~g})$ is 14 times larger than the BHT $0.08 \%$.

The tropical climate favors the occurrence of a wide variety of carotenogenic fruits in Brazil (AZEVEDO-MELEIRO; RODRIGUEZ-AMAYA, 2004). Carotenoids (Figure 1) are among the phytochemicals believed to be responsible for the reduced risk of developing some degenerative diseases. The color and biological activity of carotenoids depend on their structures. The conjugated polyene chromophore determines not only the light absorption properties, and hence color, but also the chemical reactivity of carotenoids toward oxidizing agents and free radical, and hence for any antioxidant role. Carotenoids as lycopene and $\beta$-carotene are known by their antioxidant activities; $\beta$-carotene and $\alpha$-carotene, but not lycopene, are pro-vitamin A. The highly unsaturated carotenoids are also prone to isomerization and oxidation (RODRIGUEZ-AMAYA, 1999). The aim of this study was to evaluate by first time the carotenoids profile and total polyphenols present in fruits of P. aculeata.

\section{MATERIAL AND METHODS}

Mature fruits of $P$. aculeate were collected in august of 2007 in Distrito Federal region. The ripe stage of the fruits was determined by the fruit firmness and surface color (red-orange). Ripe fruits free of defects were selected and frozen at $-20^{\circ} \mathrm{C}$ into analysis moment. The fruits were homogenized in a multiprocessor and all analysis was done in four replicates.

Butylated hydroxytoluene (95\% BHT) was from Sigma, analytical grade petroleum ether (40-60 ${ }^{\circ} \mathrm{C}$ ) was from Riedel and $n$-hexane was from Merck. HPLC grade acetonitrile, methanol and ethyl acetate were Mallinckrodt. Other analytical grade chemicals were obtained from local marked (Vetec).

Trans- $\beta$-carotene 30\% FS (UE00607050) was obtained from DSM Nutritional Product (France); after appropriate dilution (petroleum ether) the concentration of standard solution was determined at $450 \mathrm{~nm}$ using molar absorptivity equal to 2592 (petroleum ether). Other carotenoid standards were purified from passion fruit and kale leaves, according to Kimura e Rodriguez-Amaya (2002). Briefly, the carotenoids were extracted with cold acetone, saponified, if necessary hydrolyses the carotenol esters (passion fruit), and separated on magnesium oxide - hyflosupercel (1:2) open-column, using gradient of acetone in petroleum ether as mobile phase. Only the main portion of each band of carotenoid was collected. The purity of the carotenoid was determined by HPLC-PAD and the standard solutions were properly corrected.

Carotenoid analysis was carried out with protection from light, exclusion of oxygen, avoiding high temperatures and using antioxidant. All procedures were made according to AZEVEDOMELEIRO AND RODRIGUEZ AMAYA (2004). Briefly, the carotenoids from $20 \mathrm{~g}$ of $P$. aculeate pulp were extracted with cold acetone, 4 to 5 times, until complete residue lack of color. The pigments were transferred from the acetone to the petroleum ether $40-60{ }^{\circ} \mathrm{C}$. Butylated hydroxytoluene $(0.1 \%)$ was added to minimize the oxidation of the carotenoids. Extracts were saponified overnight, using equal volume of $10 \%$ potassium hydroxide in methanol. Saponified extract was washed with distillated water, until a $\mathrm{pH}$ near to neutrality. About $4 \mathrm{~mL}$ of extract was evaporated under nitrogen, dissolved in acetone and filtered in a $0.45 \mu \mathrm{m}$ PTFE syringe filter (Millipore); $10 \mu \mathrm{L}$ was automatically injected into the HPLC system.

HPLC-PAD analysis were carried out on a ProStar Varian separation module equipped with a quaternary pump and autosampler injector, controlled by Galaxie workstation. It was used a monomeric $\mathrm{C}_{18}$ column (Waters Spherisorb ODS-2, $3 \mu \mathrm{m}, 150 \mathrm{x}$ $4.6 \mathrm{~mm}$ ). The mobile phase consisted of acetonitrile (containing $0.05 \%$ of triethylamine), methanol and ethyl acetate from 95:5:0 to 60:20:20 in $20 \mathrm{~min}$, maintaining the latter proportion until the end of the run (60 $\mathrm{min}$ ). Reequilibration took $20 \mathrm{~min}$ and the flow rate was $0.5 \mathrm{~mL} \cdot \mathrm{min}^{-1}$.

The carotenoids were identified according to: a) its retention time, using carotenoids standards analyzed in the same chromatographic conditions; b) its wavelength of maximum absorption $(\lambda \max )$ on diode array detector; and c) its fine structure (\% III/II - which is expressed by the ratio between the peak height of the longest-wavelength absorption band (III) and the middle absorption peak, generally $\lambda \max (\mathrm{II})$, making up the minimum between the two peaks as the baseline, multiplied by 100).

Concentration of each identified carotenoid was carried out by external standardization. Standard curves were prepared using five or six different points of concentration for $\beta$-cryptoxanthin $(r=0.999)$, lutein $(r=0.999)$ and $\beta$-carotene $(r=0.997)$. Inferior limit of linearity was calculated to $\beta$-carotene standard $\left(8.2 \mu \mathrm{g} . \mathrm{mL}^{-1}\right) . \alpha$-carotene and $\alpha$-cryptoxanthin 
were estimated using $\beta$-carotene and $\beta$-cryptoxanthin standard curves, respectively. The provitamin A was calculated according to the new conversion factor (IOM, 2001), in which $12 \mu \mathrm{g}$ of $\beta$-carotene and $24 \mu \mathrm{g}$ of $\alpha$-carotene, $\alpha$-cryptoxanthin and $\beta$-cryptoxanthin correspond to 1 RAE (retinol activity equivalent). The average computer calculated (Excel) were determined for carotenoid concentration and provitamin A value.

Total polyphenols were extracted with solvent A (ethanol $95 \%$ at $90{ }^{\circ} \mathrm{C}$ for $30 \mathrm{~min}$ ) and solvent B (methanol-water-acetic acid 27: 3: 1.5 at ambient temperature overnight). Total phenolic was determined spectrophotometrically using Folin Ciocalteou reagent at $760 \mathrm{~nm}$; it was expressed as $\mathrm{mg}$ of gallic acid equivalent (GAE) (XU; CHANG, 2009). Total condensed tannin was determined using vanillin method at $510 \mathrm{~nm}$; it was expressed as $\mathrm{mg}$ of catechin equivalent (CAE) (BROADHURST; JONES, 1978).

\section{RESULTS}

The identified carotenoids in $P$. aculeata fruits (Figure 1) are presented in Table 1. The trans- $\beta$ carotene was identified by co-chromatography with standard and visible absorption spectrum in mobile phase and little fine structure (\%III/II) consistent with $\beta$-carotene standard eluted in the same conditions. Cis- $\beta$-carotene eluted very close to trans- $\beta$-carotene and had $\lambda \max 2-6 \mathrm{~nm}$ lower than trans- $\beta$-carotene and presented appearance of a cis peak. The $\alpha$-carotene eluted close to trans- $\beta$-carotene and was identified by visible absorption spectrum in mobile phase $6-7 \mathrm{~nm}$ lower than trans- $\beta$-carotene and by its fine structure (\%III/II) higher than trans- $\beta$-carotene standard and consistent with literature data.

Two monohydroxy carotenoids were detected. One had the same absorption spectrum of trans- $\beta$-carotene standard and was identified as $\beta$-cryptoxanthin. The other had the same spectrum of $\alpha$-carotene and presented more defined spectral fine structure compared to that of $\beta$-carotene; it may be identified as zeinoxanthin or $\alpha$-cryptoxanthin. The dihydroxy carotenoid with visible spectra and fine structure like as $\beta$-carotene, but with lowest retention time was identified as lutein.

The content of $\beta$-carotene ( $\left.34.3 \mu \mathrm{g} \cdot \mathrm{g}^{-1}\right)$ and $\alpha$-carotene $\left(22.7 \mu \mathrm{g} \mathrm{g}^{-1}\right)$ were $48 \%$ and $32 \%$ of total carotenoids, respectively. Palmaceae fruits, such as buriti $\left(364 \mu \mathrm{g} \cdot \mathrm{g}^{-1}\right)$, tucumã $\left(99 \mu \mathrm{g} \cdot \mathrm{g}^{-1}\right)$ or bocaiuva (59 $\left.\mu \mathrm{g} . \mathrm{g}^{-1}\right)$ are richer in $\beta$-carotene. However, between other fruits described in the Brazilian database of carotenoids (RODRIGUEZ-AMAYA et al., 2008), only acerola "Olivier" $\left(38 \mu \mathrm{g} \cdot \mathrm{g}^{-1}\right)$ is better source of $\beta$-carotene than $P$. aculeate fruit analyzed in this study. Canistel, other tropical fruit, presented $7,1 \mu \mathrm{g} / \mathrm{g}$ of $\beta$-carotene (AGOSTINI-COSTA et al., 2010). Buriti is the unique fruit richer in $\alpha$-carotene $\left(80 \mu \mathrm{g} . \mathrm{g}^{-1}\right)$ than $P$. aculeate analyzed; other substantial sources are found in carrot (9.8 to $\left.35 \mu \mathrm{g} . \mathrm{g}^{-1}\right)$ and some varieties of squash and pumpkin ( 0.1 to $\left.47 \mu \mathrm{g} . \mathrm{g}^{-1}\right)$ (RODRIGUEZAMAYA et al., 2008). The content of $\alpha$ - and $\beta$-carotene is very important because they are provitamin $\mathrm{A}$, but $\alpha$-carotene has only one-half of the provitamin activity of $\beta$-carotene. Lutein is the predominant carotenoid in leaves and green vegetables, but it is uncommon in fruits. The content of lutein $\left(6.5 \mu \mathrm{g} . \mathrm{g}^{-1}\right)$ was lower than $\alpha$ - and $\beta$-carotene in $P$. aculeata, however it was the highest value when compared with other fruits, being cajá $\left(5.6 \mu \mathrm{g} . \mathrm{g}^{-1}\right)$ the best value of lutein found between fruits of Brazilian database of carotenoids (RODRIGUEZ-AMAYA et al., 2008).

The $P$. aculeata fruit may be a good source of provitamin A carotenoids (401 RAE. $100 \mathrm{~g}^{-1}$ ). The value found is higher than others very good sources of provitamin A such as mango (35-215 RAE. $\left.100 \mathrm{~g}^{-1}\right)$ and acerola (35-325 RAE. $\left.100 \mathrm{~g}^{-1}\right)$. This value is only lowest than a few fruits very rich in provitamin A, especially Palmaceae such as buriti (3531 RAE.100g $\mathrm{g}^{-1}$ ), tucumã (844 RAE.100 $\mathrm{g}^{-1}$ ) and bocaiuva (510 RAE. $\left.100 \mathrm{~g}^{-1}\right)$ or pitanga (76-552 RAE. $100 \mathrm{~g}^{-1}$ ) (RODRIGUEZ-AMAYA et al., 2008). According to the estimated mean requirement of vitamin A by Fao-Who (2002), $100 \mathrm{~g}$ of P. aculeate fruit analyzed in this study would provide more than $100 \%$ of daily requirement for adults $(300 \mu \mathrm{g}$ RAE. day $\left.^{-1}\right)$.

The phenolic extraction of $P$. aculeata fruits using ethanol at $90{ }^{\circ} \mathrm{C}$ (better solvent) resulted at $64.9 \pm 1.1 \mathrm{mg}$ of gallic acid equivalent (GAE. $100 \mathrm{~g}^{-1}$ ) using Folin Ciocalteou method and $14.8 \pm 0.2 \mathrm{mg}$ of catechin equivalent (CAE. $100 \mathrm{~g}^{-1}$ ) using vanillin method for condensed tannins. Other tropical fruits are sources of phenolic compounds, like as coquinho-azedo (78-166 mg.100g $\mathrm{g}^{-1}$ ) (FARIA et al., 2008), açaí $\left(136.8 \mathrm{mg} .100 \mathrm{~g}^{-1}\right)$, guava $\left(83.0 \mathrm{mg} .100 \mathrm{~g}^{-1}\right)$, graviola ( $\left.84.3 \mathrm{mg} .100 \mathrm{~g}^{-1}\right)$ and passion fruit $(20.0$ mg. $\left.100 \mathrm{~g}^{-1}\right)($ KUSKOSKI et al, 2006). 
TABLE 1 - Identifying parameters and carotenoid concentrations of Pereskia aculeata pulp, using HPLC analysis

\begin{tabular}{|c|c|c|c|c|c|}
\hline \multirow{2}{*}{ Peak no. } & \multirow{2}{*}{ Carotenoid } & \multicolumn{3}{|c|}{ Identification Parameters } & \multirow{2}{*}{$\begin{array}{c}\text { Concentration } \\
(\mu \mathrm{g} . \mathrm{g}-1)\end{array}$} \\
\hline & & Retention time (min) & $\lambda \max (\mathrm{nm})$ & $\%$ III/II & \\
\hline 1 & Lutein & $11.9-12.4$ & $418,445,472$ & 42 & $6.5 \pm 0.4$ \\
\hline 2 & $\alpha$-cryptoxanthin / Zeinoxanthin & $18.5-19.4$ & $419,446,473$ & 30 & $2.7 \pm 0.2$ \\
\hline 3 & $\beta$-cryptoxanthin & $19.4-20.3$ & $423,451,478$ & 10 & $2.2 \pm 0.2$ \\
\hline 4 & $\alpha$-carotene & $28.4-29.4$ & $418,445,472$ & 41 & $22.7 \pm 0.6$ \\
\hline 5 & Trans- $\beta$-carotene & 29.9-30.9 & $424,452,477$ & 10 & $34.3 \pm 0.6$ \\
\hline 6 & $C i s-\beta$-carotene & $31.5-32.7$ & $419,446,473$ & - & $2.8 \pm 0.1$ \\
\hline- & Total carotenoids & - & - & - & $71.7 \pm 1.9$ \\
\hline- & Provitamin A (RAE/100g) & - & - & - & $401 \pm 8.5$ \\
\hline
\end{tabular}

$\lambda \max (\mathrm{nm})$ : in the mobile phase, obtained by diode array detector

\% III/II: Ratio between the absorption height peaks of the upper wavelength (III) and the middle wavelenght (II), taking as baseline the minimum among both, multiplied by 100 .

$\mathrm{X} \pm \mathrm{SD}$ : Mean \pm standard deviation of three repetitions.

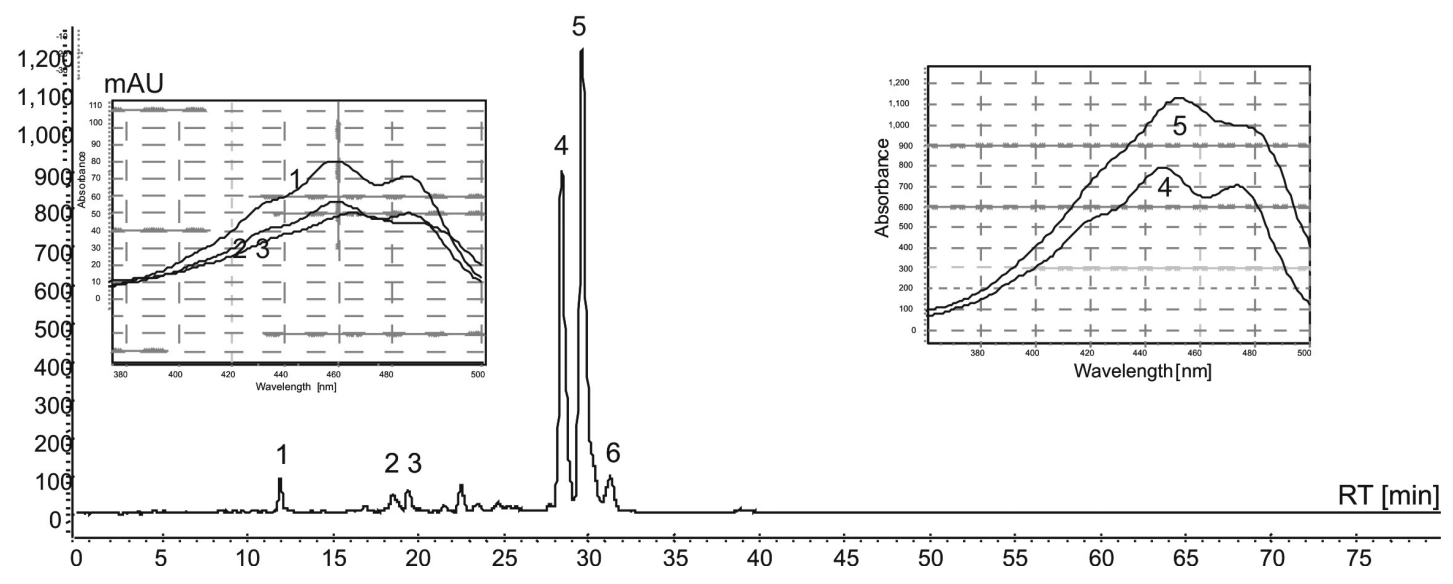

FIGURE 1 - Chromatogram of carotenoid separation of Pereskia aculeata fruits by HPLC, with respectively absorption spectrum obtained by photodiode array detector. The peak numbers and the spectrum numbers are correlated with carotenoid numbers on Table 1. 


\section{CONCLUSION}

Carotenoid identification of $P$. aculeate fruits is being presented here by first time. Results of this study indicate that these fruits may be sources of bioactive substances, specially antioxidant and provitamin A carotenoids, with potential to diversify and enrich the Brazilian human diet.

\section{REFERENCES}

AGOSTINI-COSTA, T.S.; WONDRACECK, D. C.; LOPES, R. M.; VIEIRA, R. F.; FERREIRA, F. R. Composição de carotenoides em Canistel. Revista Brasileira de Fruticultura, Jaboticabal, v. 32, n. 3, p. 903-906, 2010.

AZEVEDO-MELEIRO, C.H.; RODRIGUEZAMAYA, D.B. Confirmation of the identity of the carotenoids of tropical fruits by HPLC-DAD and HPLC-MS. Journal of Food Composition and Analysis, Roma, v. 17, p. 385-396, 2004.

BROADHURST, R. B.; JONES, W. T. Analysis of condensed tannins using acidified vanillin. Journal of the Science of Food and Agriculture, Baffins Lane Chichester, v. 29, n.9, p. 788-794, 1978.

DIAS, A. C. P.; PINTO, N. A. V. D.; YAMADA, L. T. P.; MENDES, K. L.; FERNANDES, A. G. Avaliação do consumo de hortaliças não convencionais pelos usuários das unidades do programa saúde da família de Diamantina-MG. Alimentos e Nutrição, Araraquara, v. 16, n. 3, p. 279-284, 2005.

FAO - WHO - Food and Agriculture Organization of the United Nations. Human vitamin and mineral requirements, Roma, 2002. Disponível em : $<$ http:// www.fao.org/DOCREP/004/Y2809E/y2809e0n.

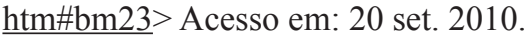

FARIA, J. P. F.; ALMEIDA, F.; SILVA, L. C. R.; VIEIRA, R. F. V.; AGOSTINI-COSTA, T. S. Caracterização da polpa de Butia capitata. Revista Brasileira de Fruticultura, Jaboticabal, v. 30, p. 820-822, 2008.

IOM - Institute of Medicine, Food and Nutrition Board; Standing Committee on the Scientific Evaluation of Dietary Reference Intakes. Dietary reference intakes: for vitamin a, vitamin $\mathrm{k}$, arsenic, boron, cromium, copper, iodine, iron, manganese, molybdenium, nickel, silicon, vanadium and zinc. Washington: National Academy Press, 2001.

KIMURA, M.; RODRIGUEZ-AMAYA, D.B. A scheme for obtaining standards and HPLC quantification of leafy vegetable carotenoids. Food Chemistry, v.78, p. 389-398, 2002.
KUSKOSKI, E. M.; ASUERO, A. G.; MORALES, M. T.; FETT. R.; Frutos tropicais silvestres e polpas de frutas congeladas: atividade antioxidante, polifenóis e antocianinas. Ciência Rural, Santa Maria, v. 36, n. 4, p. 1283-1287, 2006.

MERCÊ, A. L. R.; LANDALUZE, J. S.; MANGRICH, A. S. A.; SZPOGANICZ, B.; SIERAKOWSKI, M. R. Complexes of arabinogalactan of Pereskia aculeata and $\mathrm{Co}^{2+}, \mathrm{Cu}^{2+}, \mathrm{Mn}^{2+}$, and $\mathrm{Ni}^{2+}$. Bioresource Technology, Trivandrum, v. 76, p.29-37, 2001.

PATERSON, I. D.; DOWNIE, D.; HILL, M. P. Using molecular methods to determine the origin of weed populations of Pereskia aculeata in South Africa and its relevance to biological control. Biological Control, Orlando, v. 48, p.84-91, 2009.

RODRIGUEZ-AMAYA, D. B. A guide to carotenoid analysis in foods. Washington: International Life Sciences Institute, 1999. 64p.

RODRIGUEZ-AMAYA, D. B.; KIMURA, M.; GODOY, H. T.; AMAYA-FARFAN, J. Updated Brazilian on food carotenoids: factors affecting carotenoid composition. Journal of Food Composition and Analysis, Roma, v. 21, p. 445463, 2008.

ROSA, S. M.; SOUZA, L. A. Morfoanatomia do fruto (hipanto, pericarpo e semente) em desenvolvimento de Pereskia aculeata Miller (Cactaceae). Acta Scientiarum, Maringá, v. 25, n. 2, p. 415-428, 2003.

SILVA JÚNIOR, A.A. Ora-pro-nóbis: nutracêutico, protetor e construtor. Agropecuária Catarinense, Florianópolis, v.21, n.1, 2008.

VALENTE, L. M. M.; SCHEINVAR, L. A.; SILVA, G. C.; ANTUNES, A. P.; SANTOS, A. F. L.; OLIVEIRA, T. F.; MARCELO R. R.; TAPPIN, M. R. R.; AQUINO NETO, F. R.; PEREIRA, A. S.; CARVALHAES, S. F.; SIANI, A. S.; SANTOS, R. R.; SOARES, R. O. A.; FERREIRA, E. F.; BOZZA, M.; STUTZ, C.; GIBALDI, D. Evaluation of the antitumor and trypanocidal activities and alkaloid profile in species of Brazilian Cactaceae. Pharmacognosy Magazine, Bangalore, v. 3, n.11, p. 35-38, 2007.

XU, B; CHANG, S. K. C. Total phenolic, phenolic Acid, anthocyanin, flavan-3-ol, and flavonol profiles and antioxidant properties of pinto and black beans (Phaseolus vulgaris L.) as affected by thermal processing. Journal of Agricultural and Food Chemistry, Easton, v. 57, p. 4754-4764, 2009. 